\title{
Intermediate water links to Deep Western Boundary Current variability in the subtropical NW Atlantic during marine isotope stages 5 and 4
}

\author{
H. K. Evans, ${ }^{1}$ I. R. Hall, ${ }^{1}$ G. G. Bianchi, ${ }^{1}$ and D. W. Oppo ${ }^{2}$ \\ Received 21 December 2006; accepted 24 April 2007; published 2 August 2007.
}

[1] Records from Ocean Drilling Program Sites 1057 and 1059 (2584 m and 2985 m water depth, respectively) have been used to reconstruct the behavior of the Deep Western Boundary Current (DWBC) on the Blake Outer Ridge (BOR) from 130 to $60 \mathrm{kyr}$ B.P. (marine isotope stage (MIS) 5 and the 5/4 transition). Site 1057 lies within Labrador Sea Water (LSW) but close to the present-day boundary with Lower North Atlantic Deep Water (LNADW), while Site 1059 lies within LNADW. High-resolution sortable silt mean $(\overline{\mathrm{SS}})$ grain size and benthic $\delta^{13} \mathrm{C}$ records were obtained, and changes in the DWBC intensity and spatial variability were inferred. Comparisons are made with similar proxy records generated for the Holocene from equivalent depth cores on the BOR. During MIS 5e, SS evidence at Site 1057 suggests slower relative flow speeds consistent with a weakening and a possible shoaling of the LSW-sourced shallower limb of the DWBC that occupies these depths today. In contrast, the paleocurrent record from the deeper site suggests that the fast flowing deep core of the DWBC was located close to its modern depth below $3500 \mathrm{~m}$. During this interval the benthic $\delta^{13} \mathrm{C}$ suggests little chemical stratification of the water column and the presence of a near-uniform LNADW-dominated water mass. After $\sim 111 \mathrm{kyr}$ B.P. the $\overline{\mathrm{SS}}$ record at Site 1057 increases to reach values similar to Site 1059 for the rest of MIS 5. The strengthening of flow speeds at the shallow site may correspond to the initiation of Glacial North Atlantic Intermediate Water formation also suggested by a divergence in the benthic $\delta^{13} \mathrm{C}$ records with Site 1057 values increasing to $\sim 1.2 \%$. Coupled suborbital oscillations in DWBC flow variability and paleohydrography persisted throughout MIS 5. Comparison of these data with planktonic $\delta^{18} \mathrm{O}$ records from the sites and alkenone-derived sea surface temperature (SST) estimates from the nearby Bermuda Rise suggest a hitherto unrecognized degree of linkage between oscillations in subtropical North Atlantic SST and DWBC flow.

Citation: Evans, H. K., I. R. Hall, G. G. Bianchi, and D. W. Oppo (2007), Intermediate water links to Deep Western Boundary Current variability in the subtropical NW Atlantic during marine isotope stages 5 and 4, Paleoceanography, 22, PA3209, doi:10.1029/2006PA001409.

\section{Introduction}

[2] The Atlantic Meridional Overturning Circulation (AMOC) is responsible for a substantial component of the meridional heat transport in the Atlantic Ocean [e.g., Ganachaud and Wunsch, 2000] and abrupt shifts of the AMOC are considered to have played a key role in driving the dramatic and rapid climate variability during the last glacial period [Clark et al., 2002 and references therein]. Initiation of the AMOC occurs through the production of North Atlantic Deep Water (NADW), which consists of two main components: cold and dense Lower North Atlantic Deep Water (LNADW) forming the deepest layer and Labrador Sea Water (LSW, also known as upper NADW) at an intermediate level. The renewal of LNADW is fed by

\footnotetext{
${ }^{1}$ School of Earth, Ocean and Planetary Sciences, Cardiff University, Cardiff, UK.

${ }^{2}$ Department of Geology and Geophysics, Woods Hole Oceanographic Institution, Woods Hole, Massachusetts, USA.
}

Copyright 2007 by the American Geophysical Union. 0883-8305/07/2006PA001409 the overflow of intermediate depth water formed following the convection of surface ocean waters in the Greenland, Iceland, and Norwegian (GIN) Seas [Aagaard et al., 1985; Mauritzen, 1996]. About 3.2 Sv $\left(=10^{6} \mathrm{~m}^{3} \mathrm{~s}^{-1}\right)$ of northern source water passes between Iceland and Scotland [Saunders, 1996]. In addition, a nearly equal volume of slightly colder waters pass over the shallow sill in the Denmark Strait [Dickson and Brown, 1994]. These waters form the Atlantic Deep Western Boundary Current (DWBC) along the continental slope east of Greenland. As the DWBC flows south, it encounters LSW formed by winter time convection of surface waters to an estimated depth of $\sim 1,500 \mathrm{~m}$ in the central Labrador Sea [Reid, 1994]. Some LSW which is warmer, less saline, and less dense than LNADW [Dickson and Brown, 1994] is entrained by the DWBC, which transports about 13-14 Sv of NADW equatorward [Talley and McCartney, 1982; Schmitz and McCartney, 1993]. During its passage it is progressively undercut by northward flowing colder and denser Southern Ocean waters (Antarctic Bottom Water, AABW). The intensity and flow characteristics of the DWBC are known to have varied in space (depth) and time, which is believed to be a response to 
changes in source water production [Pickart, 1992; Bianchi et al., 2001].

[3] Paleoceanographic reconstructions of past variability in the contribution of intermediate and deepwater masses in the North Atlantic are mainly based on the geochemical analyses of epifaunal benthic foraminifera. Such work is aimed at the proxy determination of the paleohydrography or paleobiogeochemistry (e.g., nutrient content) of the waters inhabited by these organisms whose shell chemistry is believed to reflect the chemistry of the bottom waters they have lived in. This method is particularly useful to detect the changing proportion of NADW and poorly ventilated AABW. The most widely employed nutrient proxy is the ratio of stable carbon isotopes of benthic foraminiferal calcite [e.g., Curry et al., 1988; Duplessy et al., 1988; Curry and Oppo, 2005]. This approach is based on the observation that the $\delta^{13} \mathrm{C}$ of $\Sigma \mathrm{CO}_{2}$ dissolved in seawater displays a distribution in the world ocean that resembles the distribution of the main global water masses [Kroopnick, 1985]. Biological nutrient cycling results in low $\delta^{13} \mathrm{C}$ in nutrient rich waters like those derived from the Southern Ocean and high $\delta^{13} \mathrm{C}$ in nutrient poor waters like those formed in the North Atlantic today. Carbon isotope gradients in the world's ocean reflect mixing between water masses and progressive oxidation of low- $\delta^{13} \mathrm{C}$ organic matter. The application of $\delta^{13} \mathrm{C}$ methods, in addition to other nutrient proxies such as $\mathrm{Cd} / \mathrm{Ca}$ [e.g., Boyle, 1988; Boyle and Keigwin, 1982], have established that circulation patterns in the Atlantic were significantly different during glacial times. Northern source waters sank only to intermediate depths, forming the so-called Glacial North Atlantic Intermediate Water (GNAIW), resulting in a shoaling of the Atlantic deepwater core layer to approximately $2000 \mathrm{~m}$, from $3000 \mathrm{~m}$ during interglacials [Boyle and Keigwin, 1987; Duplessy et al., 1988; Curry and Oppo, 2005]. Dense southern waters filled the deep glacial Atlantic below GNAIW [Boyle and Keigwin, 1987; Duplessy et al., 1988; Sarnthein et al., 1994; Curry and Oppo 2005]. However, occasional differences between estimated nutrient changes derived from benthic $\delta^{13} \mathrm{C}$ measurements suggest that variations in isotope fractionation during air-sea exchange [Broecker and Maier-Reimer, 1992; Charles et al., 1993; Lynch-Stieglitz et al., 1996, 1999; Oppo and Horowitz, 2000] and/or marine biological productivity [Mackensen et al., 2001] may also contributed to the changes in the benthic $\delta^{13} \mathrm{C}$ signal. In addition to the complications in interpreting $\delta^{13} \mathrm{C}$ mentioned above, neither benthic $\delta^{13} \mathrm{C}$ nor $\mathrm{Cd} / \mathrm{Ca}$ are conservative tracers, and therefore complementary methods (ideally not linked with the ocean's biogeochemical cycle) are required to reconstruct past changes in ocean circulation. One of these methods is sedimentological and quite distinct from geochemical proxies, as it provides physical evidence for relative changes in the intensity of the near-bottom water flow. The parameter used is the sortable silt $(\overline{\mathrm{SS}})$, the mean grain size of the 10-63 $\mu \mathrm{m}$ terrigenous sediment subfraction [McCave et al., 1995; McCave and Hall, 2006]. From modern hydrographic investigations, it is clear that there is a link between the hydrographic location of NADW and vigorous deepwater circulation [Stahr and Sanford, 1999].
However, the hydrographic signal is more likely to be geographically widespread whereas the intensity of the DWBC will be more variable because of its interactions with local bathymetry [McCave and Hall, 2006].

[4] Here we focus on reconstructing changes in the hydrography and near-bottom flow speeds of the DWBC bathing the Blake Outer Ridge (BOR) in the western subtropical North Atlantic at intermediate water depths during marine isotope stage (MIS) 5 and into MIS 4 ( 130-60 kyr) and compare this with the Holocene. The study sites are ideally located to monitor changes in the relative intensity of LNADW and LSW, a water mass whose contribution to the overall fluctuations in the AMOC over the last glacial-interglacial period remains poorly understood [e.g., Hillaire-Marcel et al., 2001; Rasmussen et al., 2003].

\section{Regional Setting}

[5] The Blake Outer Ridge is a constructional sedimentary drift that protrudes out of the continental shelf south of Cape Hatteras and north of the Bahama Islands. It forms a continuous extension of the eastern continental margin of North America (Figure 1) and was molded by the deep contour-following bottom currents of the DWBC [Flood, 1979]. The 700-km-long BOR slopes to the southeast between $\sim 2000$ and $5000 \mathrm{~m}$ water depth and is believed to have formed through interaction between the upper part of the DWBC and the lower part of the Gulf Stream (Florida Current) where it detaches from the continental shelf [Bryan, 1970; Stahr and Sanford, 1999]. These currents erode and transport sediments originating from the continental margin to the north and Blake Plateau to the south respectively [Ewing et al., 1966; Heezen et al., 1966; Laine et al., 1994]. Amos et al. [1971] found that the BOR diverted the DWBC and its fast moving core away from the western boundary, but once the DWBC rounded the deeper reaches of the ridge it flowed westward to the Blake Escarpment, before once again flowing equatorward.

[6] The depth range spanned by the BOR means that current-controlled sediment deposition occurs under the influence of each of the climatically important water masses which make up the DWBC. Stahr and Sanford [1999] subdivided the present-day water column that influences sedimentation on the BOR into four main water masses: the uppermost water mass is a shallow component of Labrador Sea Water (SLSW, 1000-1800 $\mathrm{m}$ water depth), this is underlain by LSW (1400-2800 m water depth), LNADW (2500-4100 m water depth) and deep Bottom Water (BW, $>3400 \mathrm{~m}$ water depth to the bottom) (see Table 1). This latter water mass consists of a varying mixture of northern $(84-90 \%)$ and southern $(10-16 \%)$ source waters [Stahr and Sanford, 1999]. The water depths of these boundaries overlie each other reflecting a deepening of the DWBC flow along the ridge crest and that these categories are partly based on an amalgamation of prior definitions [Stahr and Sanford, 1999].

[7] Absolute velocity profiles along the eastern flank of the BOR [Stahr and Sanford, 1999] demonstrate that the 


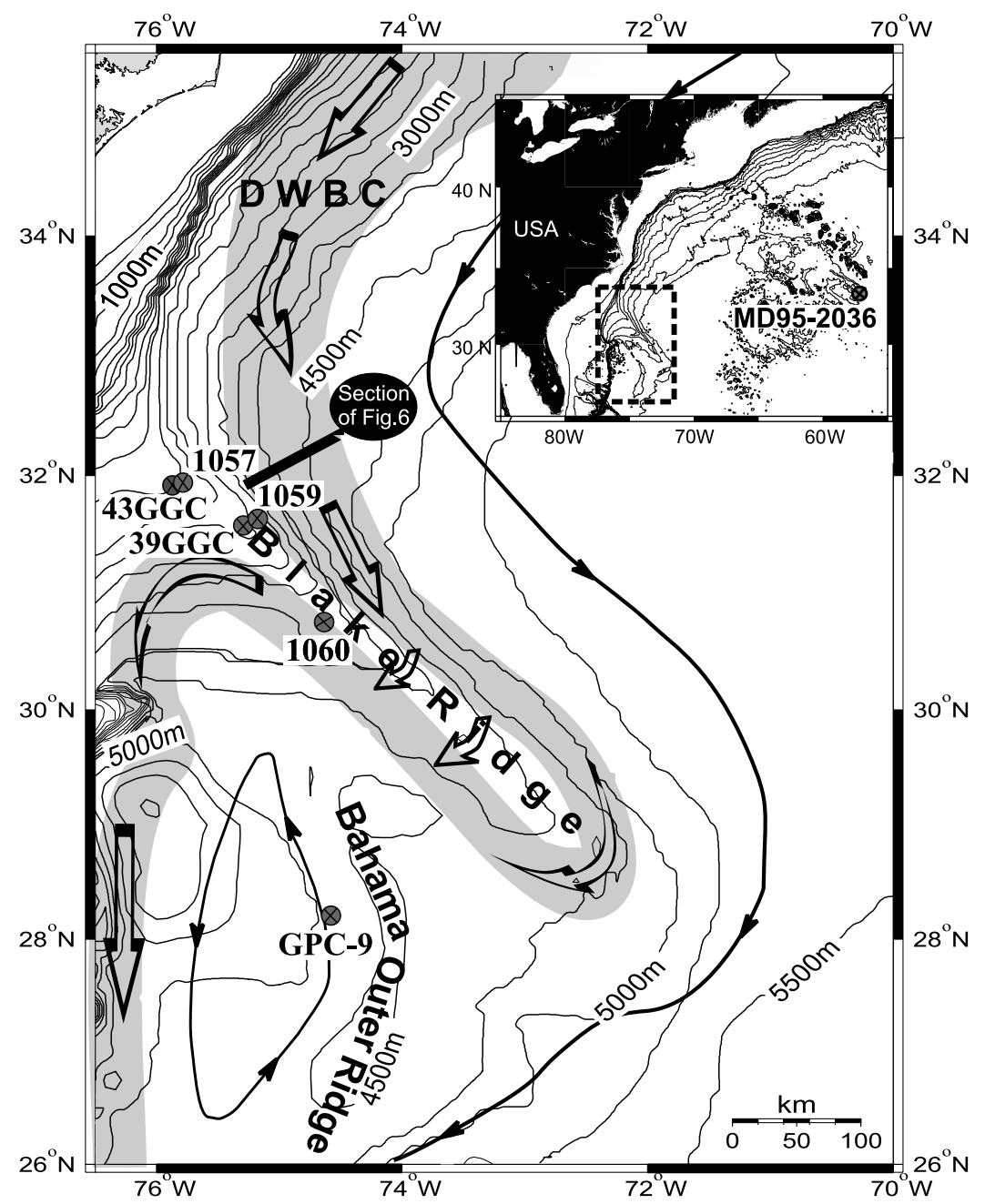

Figure 1. Bathymetric map of the study area showing the locations of sediment cores KNR 140/2 Sites 43GGC and 39GGC and the ODP Leg 172 Sites 1057 and 1059. The locations of KNR31-GPC-9 and MD95-2036 are also shown. The large arrows and the shaded area represent the fast flowing core of the DWBC [after Johns et al., 1997; Stahr and Sanford, 1999; Bianchi et al., 2001].

present-day fast flowing primary core of the DWBC is located between $3500 \mathrm{~m}$ water depth near the upstream origin of the BOR and $4100 \mathrm{~m}$ further downstream along the ridge. Johns et al. [1997] and Stahr and Sanford [1999] also document a secondary fast flowing core within SLSW between $4^{\circ}$ and $6^{\circ} \mathrm{C}(\sim 1000-1800 \mathrm{~m}$ water depth $)$ which is less constrained by topography than the deeper core and has velocity contours influencing depths down to $\sim 2500 \mathrm{~m}$.

\section{Material and Methods}

[8] We report data from sediment cores recovered from sites located either side of the present-day boundary between LNADW and LSW, and above the primary fast

Table 1. Limits and Characteristics of the Climatically Important Water Masses Within the DWBC

\begin{tabular}{llcc}
\hline Water Mass & \multicolumn{1}{c}{$\begin{array}{c}\text { Potential } \\
\text { Temperature Range }\end{array}$} & $\begin{array}{c}\text { Approximate Potential } \\
\text { Density Range, } \mathrm{kg} \mathrm{m}^{-3}\end{array}$ & $\begin{array}{c}\text { Approximate } \\
\text { Depth, } \mathrm{m}\end{array}$ \\
\hline SLSW & $6^{\circ} \mathrm{C}>\theta \geq 4^{\circ} \mathrm{C}$ & $41.00<\sigma_{3} \leq 41.27$ & $1000-1800$ \\
LSW & $4^{\circ} \mathrm{C}>\theta \geq 2.8^{\circ} \mathrm{C}$ & $41.27<\sigma_{3} \leq 41.44$ & $1400-2800$ \\
LNADW & $2.8^{\circ} \mathrm{C}>\theta \geq 1.9^{\circ} \mathrm{C}$ & $41.44<\sigma_{3} \leq 41.55$ & $2500-4100$ \\
BW & $6^{\circ} \mathrm{C}>\theta \geq 4^{\circ} \mathrm{C}$ & $\sigma_{3}<41.55$ & 3400 to bottom \\
\hline
\end{tabular}

${ }^{a}$ Reprinted with permission from Stahr and Sanford [1999]. Copyright Elsevier 1999. 
flowing core of the DWBC but below the shallower secondary core. The investigation of MIS 5 and the $5 / 4$ transition utilizes cores from Sites 1057 and 1059 of the Ocean Drilling Program (ODP) Leg 172. Site 1059 $\left(31^{\circ} 40.5^{\prime} \mathrm{N}, 75^{\circ} 25.1^{\prime} \mathrm{W}\right.$; Figure 1$)$ is located at a water depth of $2985 \mathrm{~m}$ on a small sediment drift superimposed on the BOR [Keigwin et al., 1998; Keigwin and Schlegel, 2002] and the shallower Site $1057\left(32^{\circ} 01.8^{\prime} \mathrm{N}, 76^{\circ} 04.8^{\prime} \mathrm{W}\right.$; Figure 1) is at $2584 \mathrm{~m}$ water depth. In addition, we use sediments recovered from R/V Knorr cruise KNR 140/2, the site survey cruise for Leg 172 [Keigwin, 2004], to study the Holocene at corresponding water depths to Sites 1059 and 1057. The deeper of the sites is $39 \mathrm{GGC}\left(31^{\circ} 40.1^{\prime} \mathrm{N}\right.$, $75^{\circ} 24.9^{\prime} \mathrm{W}$; Figure 1) at a water depth of $2975 \mathrm{~m}$, while $43 \mathrm{GGC}\left(32^{\circ} 01.0^{\prime} \mathrm{N}, 76^{\circ} 04.0^{\prime} \mathrm{W}\right.$; Figure 1) is situated at $2590 \mathrm{~m}$ water depth. Sediments from Site 1059 and core 39 GGC are located within LNADW at a depth that is highly sensitive to changes in the composition of this water mass and particularly the degree of mixing with waters of southern origin from below. Site 1057 and core 43GGC are located in LSW, but close to the boundary between LSW and LNADW and are therefore ideally positioned to record changes in the relative influence of LSW and LNADW.

[9] Stable isotope records based on the benthic foraminifera Cibicidoides wuellerstorfi for Site 1059 during the 145$65 \mathrm{kyr}$ interval (27.96 and 39.12 meters composite depth (mcd), average sample resolution of $5 \mathrm{~cm}$ ) were previously published by Oppo et al. [2001] and Heusser and Oppo [2003], while benthic $\delta^{13} \mathrm{C}$ data for core 39GGC (Cibicidoides spp.) are taken from Keigwin and Schlegel [2002]. Planktonic $\delta^{18} \mathrm{O}$ records for cores $39 \mathrm{GGC}$ and $43 \mathrm{GGC}$ are from Keigwin [2004] and based on Globigerinoides ruber (white variety). In addition, Site 1057 was sampled every $5 \mathrm{~cm}$ between 11.48 and $13.98 \mathrm{mcd}$. We present new planktonic and benthic stable isotope data for Site 1057 determined on $G$. ruber and $C$. wuellerstorfi respectively at Woods Hole Oceanographic Institute (WHOI) using a Finnigan MAT252 and calibrated to Vienna Pee Dee Belemnite (VPDB) following standard procedures [Keigwin and Boyle, 1999]. The long-term analytical precision based on over 2000 analysis of NBS-19 is $\pm 0.07 \%$ for the $\delta^{18} \mathrm{O}$ data and $\pm 0.03 \%$ o for the $\delta^{13} \mathrm{C}$ measurements [Ostermann and Curry, 2000]. Unfortunately, benthic $\delta^{13} \mathrm{C}$ data could not be obtained from core 43 GGC because of the absence of suitable benthic foraminifera.

[10] Samples for sedimentological analyses were disaggregated in purified water on a rotating carousel for 24 hours before being washed over a $63 \mu \mathrm{m}$ screen to separate the "coarse" and "fine" fractions. The residues were dried at $50^{\circ} \mathrm{C}$ and weight percentage of the $<63 \mu \mathrm{m}$ and $>63 \mu \mathrm{m}$ fractions was determined by weighing.

[11] The biogenic calcium carbonate (\% wt) contents for Sites 1059 and 1057 and cores 39GGC and 43GGC were indirectly estimated using a Carlo Erba EA1106 elemental $\mathrm{CHN}$ analyzer to measure the inorganic carbon content. All $\overline{\mathrm{SS}}$ grain size measurements were undertaken using a Coulter Multisizer III following the methods described by Bianchi et al. [1999]. Measurements were made on the $<63 \mu \mathrm{m}$ terrigenous fraction following the removal of the biogenic carbonate by slow digestion in $1 \mathrm{M}$ acetic acid solution. Generally, the samples used in this study have an SS abundance of $8-10 \%$ enabling the determination of the $\overline{\mathrm{SS}}$ with an error of $2.1 \%$ and $0.3 \%$ respectively [Bianchi et al., 1999]. The $\overline{\mathrm{SS}}$ values obtained from analysis on the Coulter Counter cannot be directly compared with previous paleocurrent studies for MIS 5e based on Sedigraph measurements [e.g., Bianchi et al., 2001] as these two techniques use different principles to calculate the $\overline{\mathrm{SS}}$. The Coulter Counter measures the volume-equivalent spherical diameter inferred from electrical conductivity, while the Sedigraph provides a velocity-equivalent spherical diameter based on the settling principle (Stokes Law and assuming quartz densities) inferred from an X-ray scanning settling tube [McCave and Hall, 2006].

\section{Chronology}

[12] The benthic and planktonic $\delta^{18} \mathrm{O}$ stratigraphy for Sites 1059 and 1057 are shown in Figure 2. The temporal framework for Site 1059 is based on the previously published age model of Heusser and Oppo [2003], in which the benthic $\delta^{18} \mathrm{O}$ record was correlated to the chronology of Martinson et al. [1987]. This core provides the reference age model for all the other cores utilized in this study during MIS 5 and 4. The age model for Site 1057 was generated by graphic correlation to the chronology of Heusser and Oppo [2003] (Figure 2). Initially, the benthic $\delta^{18} \mathrm{O}$ isotopes were used to broadly correlate the two records (Figure 2a) and then the higher-resolution planktonic $\delta^{18} \mathrm{O}$ isotopes were used to fine tune the correlation (Figure 2b). Correlation between the planktonic $\delta^{18} \mathrm{O}$ records was mainly focused during the youngest part of the record between 65-75 kyr B.P. where the benthic $\delta^{18} \mathrm{O}$ record experiences some correlation difficulties. A notable period of light benthic $\delta^{18} \mathrm{O}$ values between 74 and $68 \mathrm{kyr}$ in Site 1057 is difficult to reconcile with Site 1059 as can be observed in Figure 3c. However, there is a close similarity between the planktonic $\delta^{18} \mathrm{O}$ records during this interval allowing some confidence in our age assignment.

[13] A number of previously published records are introduced for comparison in section 5. In order to place each of these previously published records on a common timescale we have adjusted their chronologies to that of Site 1059 [Heusser and Oppo, 2003]. The age models of Site 1060 [Bianchi et al., 2001] at the BOR and KNR31-GPC-9 [Keigwin et al., 1994] on the Bahama Outer Ridge (BahOR) were adjusted via correlation of their benthic $\delta^{18} \mathrm{O}$ records with Site 1059. Core MD95-2036 [Lehman et al., 2002] at the Bermuda Rise was also modified on the basis of a correlation between its benthic $\delta^{18} \mathrm{O}$ record [Adkins et al., 1997; Lehman et al., 2002] and that of Site 1059, followed by fine tuning the MD95-2036 alkenone-derived sea surface temperature (SST) record and the planktonic $\delta^{18} \mathrm{O}$ record from Site 1059. The locations of the age control points and resulting sedimentation rates for each of the records are shown in the auxiliary materials. ${ }^{1}$

[14] The Holocene chronology for core 39GGC is based on previously published AMS dates [Keigwin and Schlegel,

\footnotetext{
${ }^{1}$ Auxiliary materials are available in the HTML. doi:10.1029/ 2006PA001409.
} 


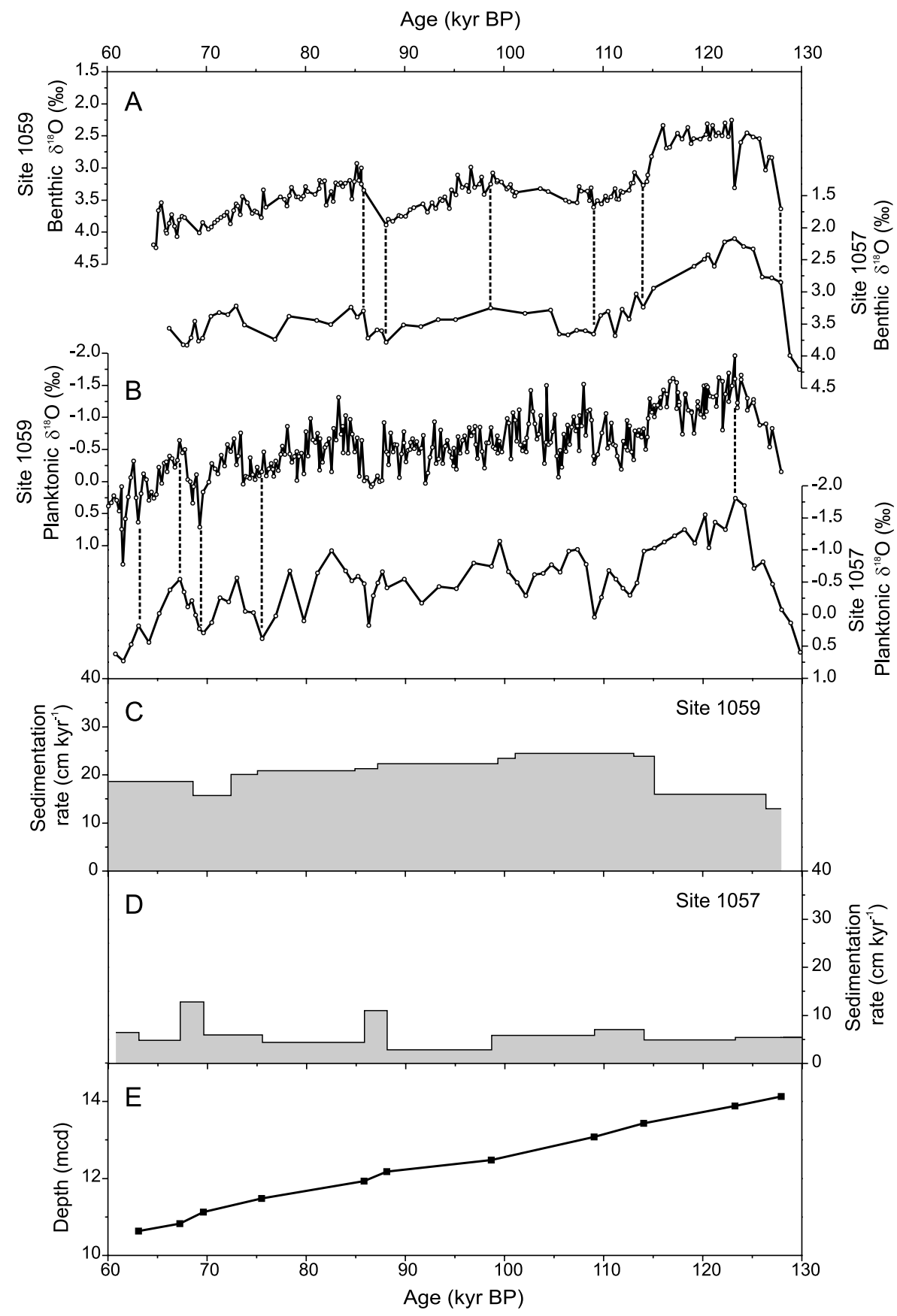

Figure 2. Chronology for Sites 1059 and 1057. (a) Benthic $\delta^{18} \mathrm{O}$ data versus age (kyr B.P.). (b) Planktonic $\delta^{18} \mathrm{O}$ data versus age (kyr B.P.) for Sites 1059 (2997 m water depth) and 1057 (2595 m water depth). (c) Sedimentation rates $\left(\mathrm{cm} \mathrm{kyr}^{-1}\right)$ for Site 1059. (d) Sedimentation rates $\left(\mathrm{cm} \mathrm{kyr}^{-1}\right)$ for Site 1057. (e) Age-depth relationship for Site 1057. Site 1059 chronology is based on Heusser and Oppo [2003]. The age model for Site 1057 was generated by graphic correlation of the benthic and planktonic $\delta^{18} \mathrm{O}$ with the Site 1059 records. Solid lines show the correlation points used.

2002], while a tentative age model for core $43 \mathrm{GGC}$ was developed using two previously unpublished AMS dates located at 35 and $67 \mathrm{~cm}$ core depth. Although a lack of benthic foraminifera prevent correlation of the benthic oxygen records and the lower sedimentation rates $(\sim 5.9 \mathrm{~cm}$ $\mathrm{kyr}^{-1}$ ) at Site 43GGC make the age model more ambiguous, it does not have a substantial effect on the broader relation- ship between the $\overline{\mathrm{SS}}$ at $43 \mathrm{GGC}$ and $39 \mathrm{GGC}$. All AMS dates were converted into calendar age using CALIB v.5.0 (M. P. Stuiver et al., CALIB 5.0, available at http://radiocarbon. pa.qub.ac.uk/calib/, 2005), assuming a reservoir correction of 400 years. Ages between age control points were estimated by linear interpolation. 


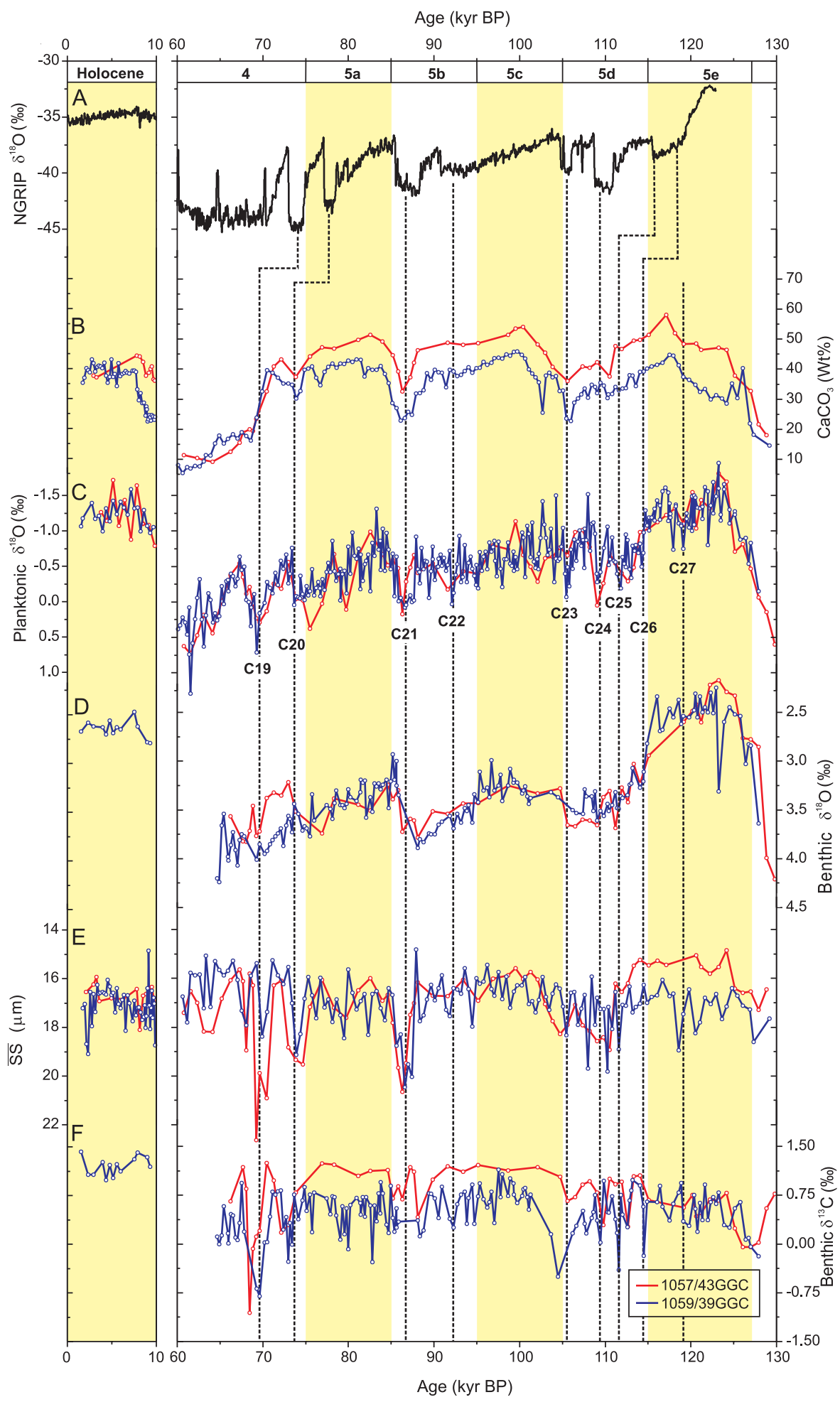

Figure 3. Holocene and MIS 5/4 proxy data for Sites 1059 and 1057 . Note axis break between 10 and $60 \mathrm{kyr}$ B.P. (top to bottom) (a) NGRIP $\delta^{18} \mathrm{O}$ [North Greenland Ice Core Project Members, 2004], (b) $\mathrm{CaCO} 3 \%$, (c) planktonic $\delta^{18} \mathrm{O}$ derived from $G$. ruber at both sites, (d) benthic $\delta^{18} \mathrm{O}$ where based on C. wuellerstorfi from Site 1059 and Cibicidoides spp. at Site 1057, (e) $\overline{\mathrm{SS}}$ (note reversed axis), and (f) benthic $\delta^{13} \mathrm{C}$ versus age (kyr B.P.). See section 5 for a description of the data origin. Records from Site 43GGC/1057 (2590/2595 m water depth) are shown in red and from Site 39GGC/1059 (2975/2985 m water depth) are shown in blue. Warm interglacial/substages are shown in yellow. Vertical dashed lines refer to previously identified cold events (labeled) [Oppo et al., 2001; Heusser and Oppo, 2003]. 
[15] At each location peak sedimentation rates typically occur during cold intervals while warmer intervals have reduced sedimentation rates. This is consistent with previous observations of low Holocene sedimentation rates at the North American continental margin [Keigwin and Jones, 1989; Haskell et al., 1991] and previous studies during the last interglacial [Bianchi et al., 2001]. The deeper sites, 1059 and 39GGC, record consistently higher sedimentation rates than the shallower sites because of the unusually high deposition rates that have led to the development of a sedimentary wave superimposed on the main sedimentary drift [Keigwin and Schlegel, 2002].

\section{Results and Discussion}

[16] Numerous previous studies of the DWBC have made use of the grain size of the detrital silt fraction of cores from the crest of the BOR in order to study paleocurrent intensity [Johnson et al., 1988; Haskell et al., 1991; Haskell and Johnson, 1993; Bianchi et al., 2001; Yokokawa and Franz, 2002]. Here we use the $\overline{\mathrm{SS}}$ grain size proxy, which provides an estimate of relative changes in near-bottom flow intensity of the depositing paleocurrent [McCave et al., 1995; McCave and Hall, 2006], with near-bottom flow speeds decreasing with distance from the fast flowing core of the DWBC [Stahr and Sanford, 1999].

[17] The $\overline{\mathrm{SS}}$ proxy can be used where the source sediment is characterized by a broad range of grain sizes and the distance to the core site is sufficient for a sorted signal to develop [McCave et al., 1995; Bianchi et al., 2001; McCave and Hall, 2006]. These conditions are met on the BOR as its supply of terrigenous sediment is principally transported by the DWBC [Heezen et al., 1966] from the American continental margin. Bianchi et al. [2001] confirmed that at Sites 1060 and 1062 on the BOR there was no significant sediment input from ice rafted debris (IRD) or turbidity current influence during the MIS 5 interval. Likewise, visual inspection and core logs from Sites 1059 and 1057, which are both located on the ridge crest and so less likely to be affected by turbidites and debris flows, show no evidence of any major down-slope deposition events.

[18] It has been shown that the DWBC changed position and migrated vertically in the water column during past climatic cycles [e.g., Ledbetter and Balsam, 1985; Johnson et al., 1988; Haskell et al., 1991; Bianchi et al., 2001]. As pointed out by Bianchi et al. [2001], at any given point in time, no single value of the $\overline{\mathrm{SS}}$ along the BOR is representative of the overall relative flow velocity of the DWBC. Therefore any sedimentological paleocurrent data from the BOR must be viewed in terms of both changing vigor at one or more given localities and position/depth of the DWBC. The records in this investigation (Figure 3) are interpreted using the same principles outlined by Bianchi et al. [2001], making the assumption that production rates of LNADW are a major control on the vertical movement of the DWBC. Therefore, as each of the core sites is located at water depths above the present-day fast flowing primary DWBC core, a synchronous increase in $\overline{\mathrm{SS}}$ at both depths is indicative of a shoaling of the DWBC core and a reduction in LNADW production.

\subsection{Paleocurrent Variability During the Holocene}

[19] Recent studies have suggested that the modern hydrographic regime in the western North Atlantic may have only been established $\sim 7$ kyr B.P. when the formation of LSW started [Hillaire-Marcel et al., 2001; Cottet-Puinel et al., 2004]. The Holocene records of cores 39GGC and 43 GGC younger than $\sim 7$ kyr should therefore be most akin to the present-day hydrographic setting at the BOR and these data offer us the chance to "ground truth" the configuration of proxy data, employed for the MIS 5 interval, to the modern setting.

[20] The $\overline{\mathrm{SS}}$ record for core $39 \mathrm{GGC}$ is suggestive of a variable DWBC throughout the Holocene (Figure 3e). Benthic $\delta^{13} \mathrm{C}$ data from core 39GGC suggest decreased ventilation of LNADW after $\sim 8 \mathrm{kyr}$ B.P. consistent with previous studies [Oppo and Fairbanks, 1987; Boyle and Keigwin, 1987]. This, in conjunction with the $\overline{\mathrm{SS}}$ data, implies greatest relative LNADW flow occurred early in the Holocene. However, the most important conclusion for this study is that the lower-resolution $\overline{\mathrm{SS}}$ record from core 43GGC displays broadly similar values to those recorded at the deeper core 39GGC. This most likely indicates the continuous presence of an active shallow limb of the DWBC, as detailed by modern hydrographic studies [Johns et al., 1997; Stahr and Sanford, 1999] in the area, elevating the $\overline{\mathrm{SS}}$ grain size at core $43 \mathrm{GGC}$. A lack of benthic $\delta^{13} \mathrm{C}$ data prevents the geochemical assessment of changes in ventilation at this site.

\subsection{Paleocurrent Variability During MIS 5 and 4}

[21] The boundaries of the MIS 5 substages [Shackleton, 1969] discussed in this study are defined according to those set out by Heusser and Oppo [2003] and are represented by areas in yellow in Figure 3. Comparing the $\overline{\mathrm{SS}}$ for Sites 1057 and 1059 across the entire MIS 5 interval and into MIS 4 reveals the changing relationship of the relative flow speeds recorded at each site. Site 1057 shows a slight increasing trend in the $\overline{\mathrm{SS}}$ throughout the record, a trend that is not present at Site 1059, although the $\overline{\mathrm{SS}}$ increases in unison at both sites during the latter part of cold substages $5 \mathrm{~d}, 5 \mathrm{~b}$ and during early stage 4 in conjunction with previously identified marine cold events (e.g., C19, C20, C21 and C23 [McManus et al., 1994; Oppo et al., 2001; Heusser and Oppo, 2003]). The $\delta^{13} \mathrm{C}$ variations at Site 1057 also show a general increase to heavier values throughout the record, intersected by lighter excursions, indicating declining or reduced deep ocean ventilation during the larger cold events (C19-C24). Site 1059 records more pronounced excursions during these cold episodes, but the $\delta^{13} \mathrm{C}$ values during the warm substages (5c and $5 \mathrm{a}$ ) remain similar to MIS $5 \mathrm{e}$ values.

[22] During MIS 5e and early 5d (Figure 3e), the shallower Site 1057 records lower $\overline{\mathrm{SS}}$ grain size values $($ mean $=$ $15.4 \mu \mathrm{m})$ than Site $1059($ mean $=17.1 \mu \mathrm{m})$ and these are the lowest $\overline{\mathrm{SS}}$ values throughout the record and are also lower than those observed in core 43GGC during the Holocene. The $\overline{\mathrm{SS}}$ offset between the two sites is reasonably constant $(1.7 \mu \mathrm{m} \pm 0.75 \mu \mathrm{m})$ and this observation strongly corroborates one of the key assumptions in this work that sedimentation in the sortable silt range on the crest of the 


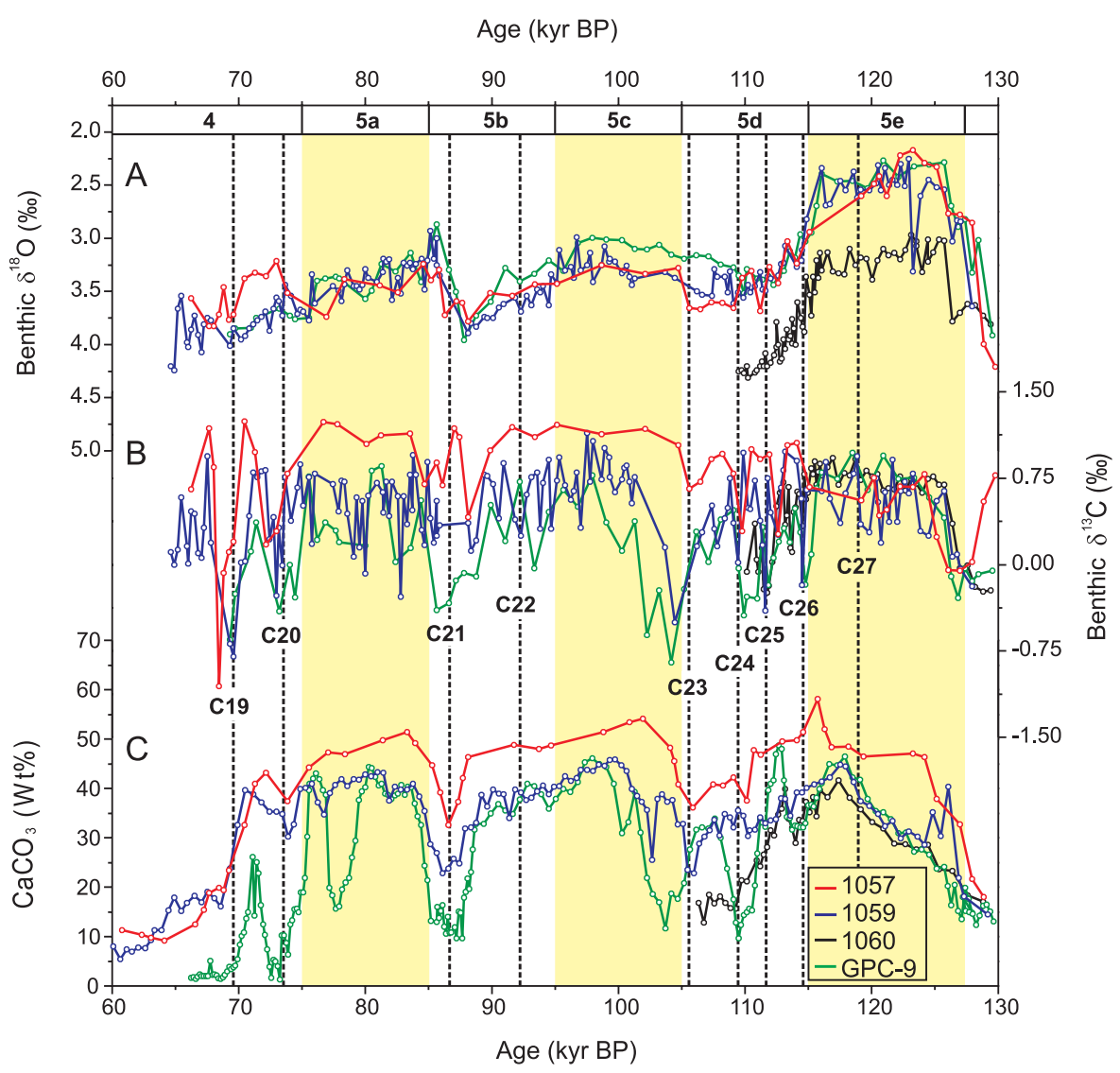

Figure 4. Extended depth range benthic isotope $\left(\delta^{18} \mathrm{O}\right.$ and $\delta^{13} \mathrm{C}$ ) and $\mathrm{CaCO}_{3}$ (wt \%) data. (top to bottom) (a) Benthic $\delta^{18} \mathrm{O}$, (b) benthic $\delta^{13} \mathrm{C}$, and (c) $\mathrm{CaCO}_{3}$ versus age (kyr B.P.). Records are shown in red (Site 1057, $2584 \mathrm{~m}$ water depth), blue (Site 1059, $2985 \mathrm{~m}$ water depth), black (Site 1060, $3480 \mathrm{~m}$ water depth), and green (GPC-9, $4758 \mathrm{~m}$ water depth). Data for Site 1060 are from Bianchi et al. [2001] and are based on Cibicidoides wuellerstorfi, Cibicidoides spp., and Uvigerina spp. The $\delta^{18} \mathrm{O}$ results for C. wuellerstorfi and Cibicidoides spp. have been corrected by $+0.64 \%$ o to account for species-dependent isotopic fractionation, and a correction of $+0.7 \%$ has been applied to the $\delta^{13} \mathrm{C}$ data for Uvigerina spp. (see Bianchi et al. [2001] for further details). The GPC-9 data from Keigwin et al. [1994] only show the Cibicidoides spp. record in this study. Warm interglacial/substages are shown in yellow. Vertical dashed lines refer to previously identified cold events (labeled) [Oppo et al., 2001; Heusser and Oppo, 2003].

BOR is predominantly controlled by deepwater currents rather than simple down slope sediment movement where coarser grain sizes would always be found at shallower depths [Haskell et al., 1991; Haskell and Johnson, 1993]. Throughout the MIS 5e interval the benthic $\delta^{13} \mathrm{C}$ (Figure 3e) at both sites are similar at around $0.7 \%$ and imply the presence of a well mixed water mass between the sites. To further investigate the extent of this water mass, benthic $\delta^{13} \mathrm{C}$ data were incorporated from two deeper sites (Figure 4), ODP Site 1060 on the BOR (3480 m water depth [Bianchi et al., 2001]) and core GPC-9 on the BahOR (4758 m water depth [Keigwin et al., 1994]). The $\delta^{13} \mathrm{C}$ data from ODP Site 1060 [Bianchi et al., 2001, Figure 4c] and GPC-9 [Keigwin et al., 1994, Figure 4] also suggest the presence of a similar water mass at greater depths.

[23] The benthic $\delta^{13} \mathrm{C}$ records during MIS 5e are indicative of a water column that is dominated by northern source waters (NSW). However, the benthic $\delta^{13} \mathrm{C}$ signature is slightly lighter than that experienced by core 39GGC in the Holocene (Figure 3f) and the $\delta^{13} \mathrm{C}$ of $\sim 1 \%$ o [Kroopnick, 1985; Curry and Oppo, 2005] associated with contemporary LNADW. This suggests poorer ventilation during MIS 5e than the Holocene, with $\delta^{13} \mathrm{C}$ values similar to those expected for the present-day BW of Stahr and Sanford [1999, section 1.2] where the influence of AABW is believed to slightly decrease the benthic $\delta^{13} \mathrm{C}$ signature [Keigwin et al., 1994]. Today, BW on the BOR is restricted to water depths below $3400 \mathrm{~m}$ and only contributes about $15 \%$ to the overall transport [Stahr and Sanford, 1999]. However, it is suggested that during peak MIS 5e a NSW mass with a similar benthic $\delta^{13} \mathrm{C}$ value to present-day $\mathrm{BW}$ extended throughout the water column, at least up to $\sim 2600 \mathrm{~m}$ water depth, at the BOR.

[24] The clear offset between the $\overline{\mathrm{SS}}$ of Sites 1057 and 1059 demonstrates that flow conditions of the DWBC were also considerably different compared to the Holocene (Figure 3e). The $\overline{\mathrm{SS}}$ record at Site 1059 suggests an 
approximately stable position for the axis of the deeper DWBC limb below at least $2985 \mathrm{~m}$ water depth, consistent with the paleocurrent reconstruction of Bianchi et al. [2001] who suggested that during MIS 5e the DWBC was located below Site 1060 (3461 m water depth). These latter data are based on Sedigraph analysis of the $\overline{\mathrm{SS}}$ component and the resulting grain sizes are therefore not directly comparable with the $\overline{\mathrm{SS}}$ estimates presented in this study.

[25] The lower $\overline{\mathrm{SS}}$ recorded at Site 1057 is suggestive of a weakened LSW production, which would have presumably caused a shoaling or possibly even a loss of the upper dynamic limb of the DWBC, which is LSW-sourced at these depths today. In the absence of any significant influence from the shallower DWBC core Site 1057 would be distant and isolated from the deeper fast flowing core of the DWBC. The formation and properties of the North Atlantic intermediate and deep water over the last interglaciation are contentious. Hillaire-Marcel et al. [2001] suggest that LSW formation was absent during the last interglacial and advocate the presence of a single water mass originating from the Nordic Seas overlain by a thin buoyant surface layer. While Rasmussen et al. [2003] conclude that LSW, with a fairly similar composition as today, was generated throughout the peak of MIS 5e. They also suggest the presence of a benthic foraminiferal "Atlantic assemblage" that does not appear to be linked to overflow water from the Nordic Seas. The compiled benthic $\delta^{13} \mathrm{C}$ record presented here strongly support the presence of a uniform water mass, dominated by LNADW below $\sim 2500 \mathrm{~m}$ on the BOR, during peak MIS 5e, with evidence from the Site 1057 flow speed record of a weakened LSW. At $2584 \mathrm{~m}$ water depth Site 1057 is located at the base of LSW influence on the BOR and therefore highly sensitive to relative changes in LSW and LNADW production and DWBC flow. However, we need to be cautious as, clearly, on the basis of our $\overline{\mathrm{SS}}$ data alone we cannot rule out continued vigorous production of SLSW ventilating shallower depths.

[26] The benthic $\delta^{13} \mathrm{C}$ records (Figure 4b) suggest an apparent reorganization in the hydrography and flow of the DWBC starting close to the MIS $5 \mathrm{e}-5 \mathrm{~d}$ boundary at $\sim 117-110 \mathrm{kyr}$ B.P. At this time a significant lowering of $\delta^{13} \mathrm{C}$ values was experienced at the two deeper sites (Sites 1060 and GPC-9) indicative of decreasing ventilation, while conditions at the two shallower sites (1057 and 1059) experience a smaller shift toward heavier values. In terms of the $\overline{\mathrm{SS}}$ records this transition is much less obvious but is marked by the onset of gradually increasing $\overline{\mathrm{SS}}$ at Site 1059 and 1057 (Figure 3e). These data support a shoaling of the water column structure in response to a decrease in LNADW production at that time [Adkins et al., 1997; Hall et al., 1998]. Such a transition is consistent with the indication of a reduction in the depth of the deep core of the DWBC suggested in the Site $1060 \overline{\mathrm{SS}}$ record at $\sim 118-$ $117 \mathrm{kyr}$ [Bianchi et al. 2001]. Bianchi et al. [2001] suggest that it was only after $\sim 113$ kyr that the core of the DWBC shoaled above Site 1060. This study further suggests that the reduced LNADW between $\sim 118-113 \mathrm{kyr}$ is part of a longer transition. At $\sim 111 \mathrm{kyr}$ B.P., a significant shift in the relationship between the $\overline{\mathrm{SS}}$ and benthic $\delta^{13} \mathrm{C}$ is observed at Sites 1057 and 1059 (Figures 3e and 3f): a $\overline{\mathrm{SS}}$ increase at
Site 1057 is responsible for the flow speed records at both sites converging and subsequently behaving more coherently through the remainder of MIS 5 and into MIS 4. We suggest that such behavior is indicative of the reestablishment of a stronger and possibly deeper secondary core of the DWBC after $\sim 111$ kyr. The strengthening and deepening of the shallower core would increase the flow speeds recorded at Site 1057 while possibly depressing the depth of the deeper flowing DWBC core. Coincident with this shift, the benthic $\delta^{13} \mathrm{C}$ records diverge and Site 1057 benthic $\delta^{13} \mathrm{C}$ values increase to typically $>1 \%$ while the long-term values at Site 1059 remain unchanged. Immediately following this divergence the benthic $\delta^{13} \mathrm{C}$ at GPC-9 reach minimum values (Figure 4b). The increased benthic $\delta^{13} \mathrm{C}$ values at Site 1057 imply the development of a clear hydrographic boundary in the $\sim 500 \mathrm{~m}$ of water column that separate the two sites. The shallower, more nutrient depleted water mass has benthic $\delta^{13} \mathrm{C}$ values slightly higher than those experienced in the Holocene at 39GGC, implying that this water mass is of a northern origin and may represent the initiation of, or a similar water mass to Glacial North Atlantic Intermediate Water (GNAIW) formation. This is supported by Chapman and Shackleton [1998, 1999] and Chapman et al. [2000] who suggest that the gradual increase in $\delta^{13} \mathrm{C}$ values in core SU90-03 $\left(40^{\circ} \mathrm{N}, 32^{\circ} \mathrm{W}, 2475 \mathrm{~m}\right.$ water depth) in the North Atlantic during MIS 5, could signify a longterm change in the depth and/or production rate of NADW. This, in conjunction with the reestablishment of the shallower core of the DWBC, could also explain the long-term increase in the $\overline{\mathrm{SS}}$ evident at Site 1057 throughout the record (Figure 3e). However, it should be noted that Oppo and Lehman [1995] documented a similar rising trend in benthic $\delta^{13} \mathrm{C}$ within MIS 5 in subpolar North Atlantic core V29-202 (2658 $\mathrm{m}$ water depth), and argued that it was driven by the changing composition of tropical surface feed waters, driven by either biological or thermodynamic processes. However, our grain size records demonstrates that a change in DWBC geometry occurred over MIS 5 and suggests that observed benthic $\delta^{13} \mathrm{C}$ values cannot be explained solely by changes in the preformed composition of the surface waters, but must involve a physical change in deep ocean circulation.

[27] Curry and Oppo [2005] demonstrate that the sharp boundary at $\sim 2 \mathrm{~km}$ in the subpolar North Atlantic between northern and southern source water masses during the LGM is eroded as GNAIW flows southward toward the BOR study sites and mixes with Southern Ocean waters. At comparable latitudes to the BOR the whole depth range from 2-4 $\mathrm{km}$ appear to be in a mixing zone. Although the precise geometry described by Curry and Oppo [2005] during the LGM may differ slightly from that experienced within MIS 5 our results suggest that once the $\delta^{13} \mathrm{C}$ gradient was established it persisted throughout the subsequent glaciation and that at least 1059 lay in a water mass gradient most of the time. This is supported by data from GPC-9 [Keigwin et al., 1994, Figure 6c], which show a similar benthic $\delta^{13} \mathrm{C}$ pattern to the shallower two sites but with a more pronounced influence of AABW.

[28] The latter parts of cold substage $5 \mathrm{~b}$ and, to a lesser extent, $5 \mathrm{~d}$ are characterized by a transient interval of 
increased $\overline{\mathrm{SS}}$ associated with significant positive excursions in the planktonic $\delta^{18} \mathrm{O}$ records at each site indicative of sea surface cooling (cold events: C24, C23 and C21; see section 5.3; Figures $3 \mathrm{c}$ and $3 \mathrm{e}$ ). A lack of benthic foraminifera, possibly due to the increased influence of corrosive southern-sourced AABW, particularly during the MIS 5b event, precludes a clear observation of the hydrographic changes associated with these intervals but do hint at reduced water column ventilation. An increase in dissolution during these intervals is consistent with the reduced $\mathrm{CaCO}_{3}$ observed (Figure 4c). The maxima in DWBC flow speeds during these intervals are indicative of a rapid shoaling of the DWBC to a depth at which the fast flowing core is close to Sites 1059 and 1057 and most likely increased influence of AABW.

[29] MIS 4 is only partly represented in our records. However, it is during this interval that the largest changes in DWBC flow speed and hydrography are recorded. Two $\delta^{13} \mathrm{C}$ excursions centered at $\sim 75$ and $\sim 69 \mathrm{kyr}$, consistent with surface cooling events C20 and C19, are associated with a substantial increase in the flow speed at Site 1057 and a smaller increase at the deeper Site 1059 (Figures 3c and 3e). This suggests a significant decrease in NADW/ GNAIW production leading to a rapid shoaling of the deeper DWBC core more proximal to and possibly above Site 1057 . These flow speed changes are accompanied by similarly abrupt excursions in the benthic $\delta^{13} \mathrm{C}$ records at both sites, and have also been previously documented on the BahOR [Keigwin et al., 1994]. In the case of the younger $\mathrm{C} 19$ event benthic $\delta^{13} \mathrm{C}$ values fall to below $-0.5 \%$ at both Site 1057 and 1059, characteristic of a water mass similar to unmodified AABW during the LGM [Oppo and Fairbanks, 1987; Curry et al., 1988]. During the interstadial intervals surrounding these cold events the benthic $\delta^{13} \mathrm{C}$ and $\overline{\mathrm{SS}}$ values return to similar levels as those observed during MIS 5a. The correlation of these events in the deep ocean to other proxies such as the $\delta^{18} \mathrm{O}$ NGRIP record which provides a temperature proxy record for the northern North Atlantic (Figure 3) highlights the potential global significance of these oscillations.

\subsection{Surface-Deep Ocean Links}

[30] Oppo et al. [2001] have previously made a detailed study comparing the planktonic $\delta^{18} \mathrm{O}$ record at Site 1059 to its benthic $\delta^{13} \mathrm{C}$ record, finding virtually synchronous oscillations between the two proxies suggestive of a persistent surface-deepwater linkage from early in MIS 5e. Oppo et al. [2001] argue that SST variability provides the simplest explanation for the suborbital oscillations (4-10 kyr pacing) in planktonic $\delta^{18} \mathrm{O}$ apparent during MIS 5, as they are similar in magnitude and timing to the planktonic $\delta^{18} \mathrm{O}$ variations in MIS 3, which have been previously attributed to SST [Keigwin and Boyle, 1999; Sachs and Lehman, 1999]. In this study it is clear that planktonic $\delta^{18} \mathrm{O}$ [Oppo et al., 2001] evidence for surface cooling, particularly during cold events $\mathrm{C} 24-\mathrm{C} 19$, is not only associated with weak NADW (low benthic $\delta^{13} \mathrm{C}$ ), but also corresponds to a shoaling DWBC as represented by increasing $\overline{\mathrm{SS}}$ values (Figure 3 ).

[31] No specific SST proxy measurements are available for MIS 5 from the BOR, so in Figure 5 we compare the
Site 1057 and 1059 proxy records with the high-resolution SST record derived from measurements of the unsaturated alkenone ratio in core MD95-2036 recovered from the nearby Bermuda Rise $\left(33^{\circ} 41.444^{\prime} \mathrm{N}, 57^{\circ} 34.548^{\prime} \mathrm{W}, 4462 \mathrm{~m}\right.$ water depth [Lehman et al., 2002]). The correlation between the SST at MD95-2036 and the planktonic $\delta^{18} \mathrm{O}$ at Sites 1057 and 1059 (Figure 5a) confirms the presence of a series of synchronous abrupt cooling events at each site. Intriguingly, comparison of the alkenone-derived SST record and the planktonic $\delta^{18} \mathrm{O}$ record of Site 1059 also reveals a lack of shorter-timescale structures in the alkenone record compared to the planktonic $\delta^{18} \mathrm{O}$ record. This finer structure in the Site 1059 planktonic $\delta^{18} \mathrm{O}$ data could be a function of changes in sea surface salinity (SSS), which is not recorded in the purely temperature-related alkenone record. Alternatively, the finer-timescale structure may be lost in the alkenone record because of mixing of alkenones of different ages in any one sample [Ohkouchi et al., 2002], or it could result from changes in seasonality, preservation or depth habitat between the two proxies [e.g., Popp et al., 2006].

[32] Lehman et al. [2002] showed a strong correlation between their alkenone record and the benthic $\delta^{13} \mathrm{C}$ data of GPC-9 on the BahOR [Keigwin et al., 1994]. They observed a clear correspondence between low SST and low $\delta^{13} \mathrm{C}$ values, which is also recorded in the $\overline{\mathrm{SS}}$ record of Hall et al. [1998] in MD95-2036, as evidence of reduced NADW formation. This has resulted in speculation that local suppression of deepwater formation is one likely mechanism for the amplification of the direct cooling effects of iceberg melting and ice sheet discharge [Lehman et al., 2002]. The relationship described by Lehman et al. [2002] together with the findings of Oppo et al. [2001] are further substantiated by the benthic $\delta^{13} \mathrm{C}$ record of Site 1059 that shows a strong relationship between colder SSTs and low benthic $\delta^{13} \mathrm{C}$ (Figure 5c), suggesting reduced LNADW formation during cold intervals with a greater influence of AABW. During MIS 5 and the 5/4 transition, this relationship is less pronounced at the shallower Site 1057 probably in part because of the lower resolution and the proximity of GNAIW that maintains high $\delta^{13} \mathrm{C}$ values. Comparison of the MD95-2036 alkenone SST record, the Site 1059 planktonic $\delta^{18} \mathrm{O}$ record and Site $1059 \overline{\mathrm{SS}}$ (Figure $5 \mathrm{~b}$ ) reveals a striking and persistent relationship throughout MIS 5 and the 5/4 transition. This suggests a very tight linkage between SST in the subtropical western North Atlantic and DWBC activity which extends north to the Bermuda Rise. The link between these shallow and deep locations may lie in the Nordic Seas. During the last interglacial surface temperature variations in the Nordic Seas coincided with deepwater changes [Fronval and Jansen, 1996; Fronval et al., 1998], with the majority of fluctuations being related to reductions in the AMOC. Furthermore, Oppo et al. [2001] suggest that during deglacial and glacial periods ocean-ice interactions and deepwater variability may amplify suborbital variability. They suggest that during the penultimate deglaciation NADW production varied between the Nordic Seas and open North Atlantic positions, similar to the situation thought to occur during the LGM [Boyle and Keigwin, 1987], and this occurred in parallel with SST oscillations. It is suggested that this situation was 


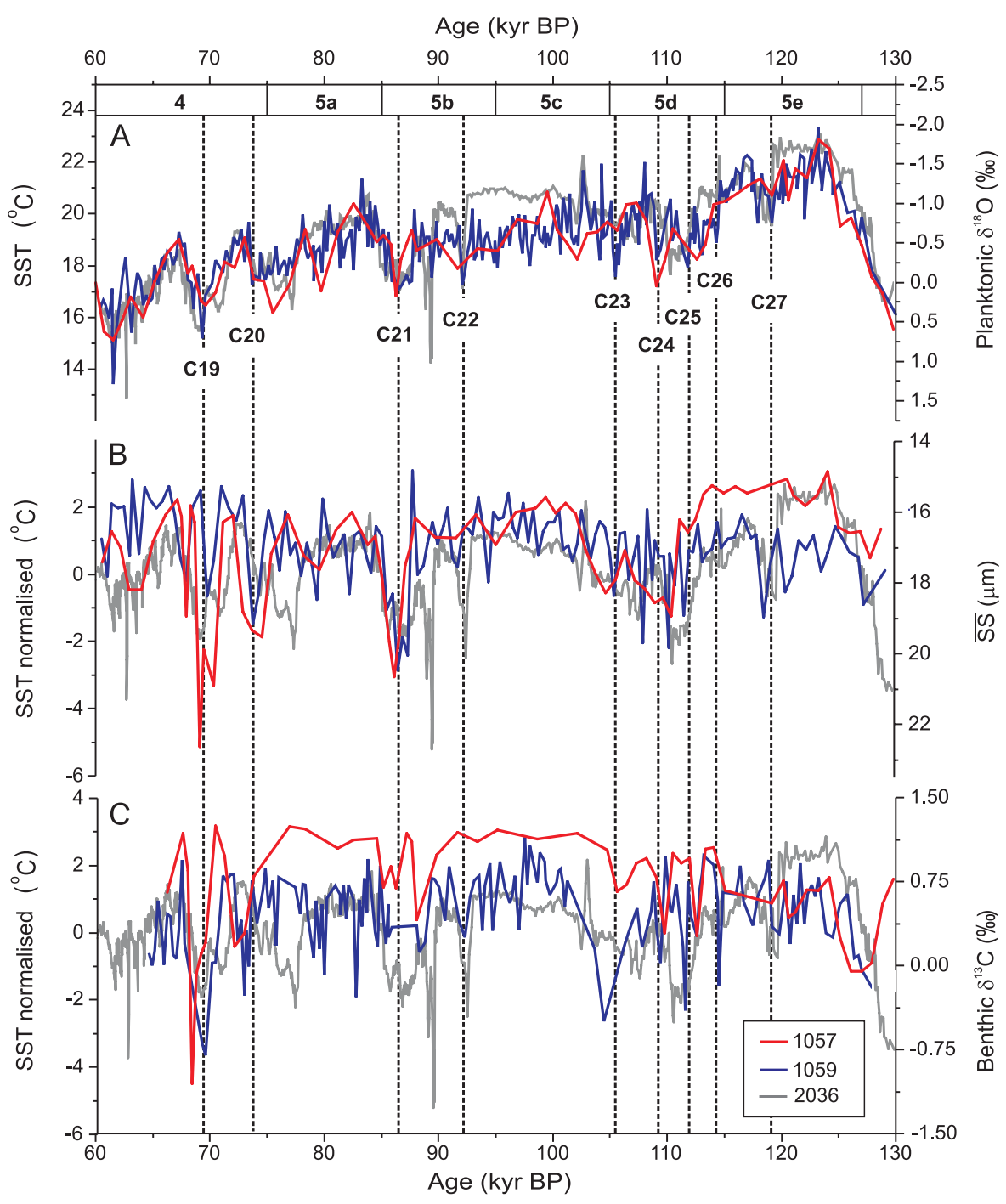

Figure 5. Comparison of the alkenone-derived SST from Bermuda Rise core MD95-2036 [Lehman et al. 2002] and Sites 1059 and 1057 proxy records. (a) MD95-2036 alkenone-derived SST along with planktonic $\delta^{18} \mathrm{O}$ for Sites 1057 and 1059. (b) SST normalized using a simple second-order polynomial regression along with $\overline{\mathrm{SS}}$ results for Sites 1057 and 1059. (c) Normalized SST along with the benthic $\delta^{13} \mathrm{C}$ data for Sites 1057 and 1059. Vertical dashed lines refer to previously identified cold events (labeled) [Oppo et al., 2001; Heusser and Oppo, 2003].

not confined to the penultimate deglaciation but played an important role throughout MIS 5 and into MIS 4, with warm water penetrating into the Nordic Seas resulting in melting of ice and a weakening of NADW formation [Oppo et al., 2001]. The effects of these intervals of weaker and shallower NADW formation are not confined to the marine environment. They can also be linked to cold events in the terrestrial pollen record of the southeastern United States [see Heusser and Oppo, 2003] and the larger oscillations (C19-C24) have cold counter parts in the Greenland Ice core records (Figure 3). Although the cause of such suborbital variability remains unknown, the observed variations in deepwater circulation and the associated northward transport of heat are likely to have played an important role communicating the climatic variation throughout the wider circum-North Atlantic region [Heusser and Oppo, 2003].

\section{Summary and Conclusions}

[33] This study presents the first comprehensive $\overline{\mathrm{SS}}$ records and $\delta^{13} \mathrm{C}$ gradients between sites on multiple cores for MIS 5 and early MIS 4. A schematic representation of the water column and high-velocity core of the DWBC on the eastern flank of the BOR during the major intervals discussed above is presented in Figure 6. Paleocurrent and hydrographic reconstructions suggest that the configuration of DWBC flow was substantially different during peak MIS 5e from the Holocene with strong evidence for a weakened LSW influence. Instead, a well mixed water 
A Holocene

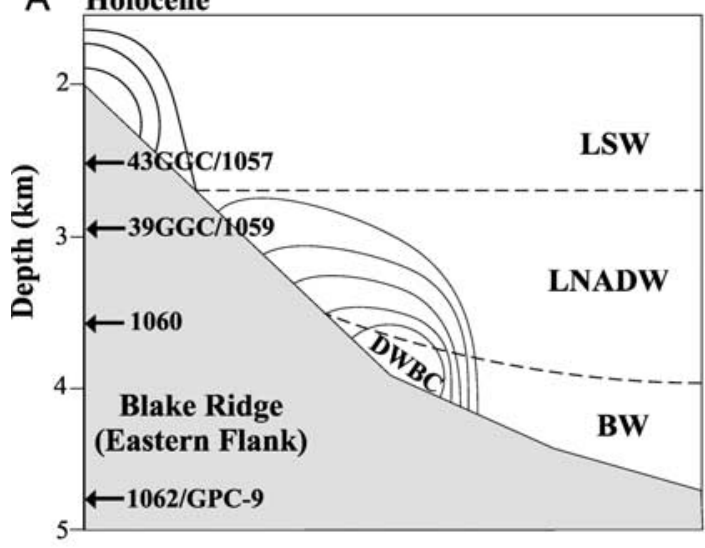

C MIS 5 after $\sim 111$ kyr BP

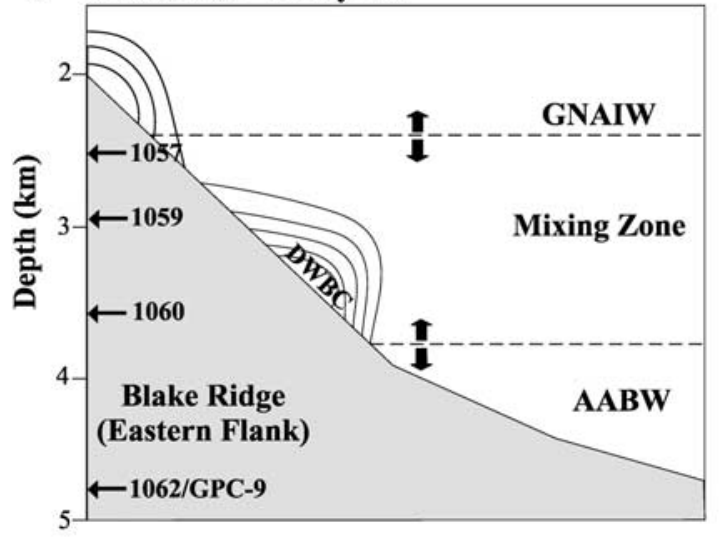

B MIS 5e

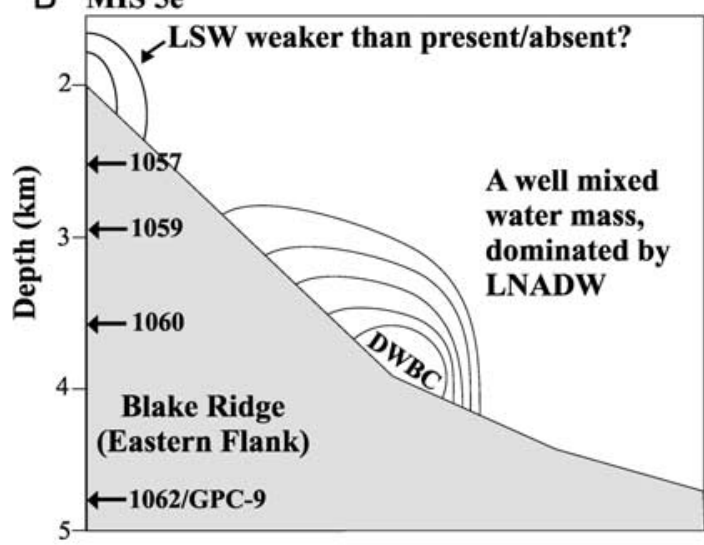

D Cold Events C19, C20, C21 and C23

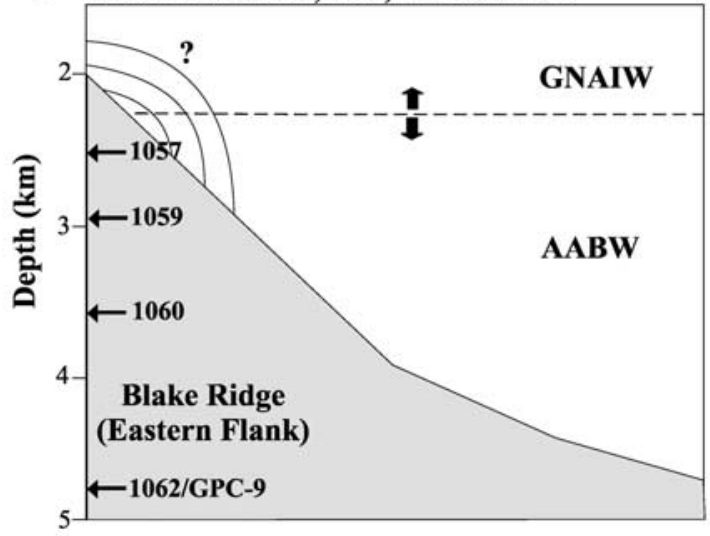

Figure 6. Schematic representations of the high-velocity core of the DWBC on the eastern flank of the BOR. (a) Present day [after Stahr and Sanford, 1999]. (b) Peak MIS 5e. The influence of LSW and the shallow core have been reduced. The main axis of the current remains close to its present position but with the presence of a well-mixed water mass. (c) MIS 5 after $\sim 111$ kyr B.P., with the reinitiation of the shallower secondary core of the DWBC. LNADW has been replaced by a GNAIW-like water mass. The sites sit in the gradient between these water masses. (d) Marine cold events C19, C20, C21, and C23 showing an incursion of AABW to shallower depths and a shoaling of the high-velocity core of the DWBC proximal to Sites 1059 and 1057. The boundaries of the various water masses defined within the text are shown by dashed lines along with the depths not the positions of the sites under investigation. Arrows indicate the fluctuating behavior of the water mass boundaries. The position of these idealized cross sections is shown in Figure 1.

mass, dominated by LNADW but less well ventilated than during the Holocene was present over a broad depth range from $2584 \mathrm{~m}$ to $4758 \mathrm{~m}$ water depth. We show that the MIS 5e configuration was terminated by a significant shift in DWBC flow characteristics coincident with a hydrographic change that began as early as $\sim 118-117 \mathrm{kyr}$ culminating in the transition midway through MIS $5 \mathrm{~d}$. It appears this shift may represent the initiation of GNAIW formation, with Sites 1057 and 1059 lying in the gradient between nutrient depleted GNAIW and nutrient enriched AABW for the remainder of MIS 5 confirming that the Atlantic was stratified during MIS 5d-5a [Chapman and Shackleton, 1998, 1999]. Large correlative suborbital oscillations during the latter part of the cold substages MIS $5 \mathrm{~d}$ and $5 \mathrm{~b}$, as well as early MIS 4 can be correlated to the surface cooling events of McManus et al. [1994], and imply a rapid shoaling of the DWBC high-velocity core and incursions of AABW to shallower depths. Such data demonstrate that the $\delta^{13} \mathrm{C}$ variations suggested to be related to abrupt deepwater hydrographic variations are also associated with large-scale dynamic changes in the DWBC flow. Furthermore, comparison with surface ocean oxygen isotope records and the alkenone-derived SST estimates for core MD95-2036 on the Bermuda Rise [Lehman et al., 2002] highlight a persistent link between subtropical North Atlantic surface ocean climate and the dynamics of the underlying DWBC. The results of this study demonstrate the importance of using multiple proxies related to both the hydrographic properties of deep ocean water masses and 
dynamical tracers of deep ocean flow in order to provide a better appreciation of past AMOC variability.

[34] Acknowledgments. We thank Lloyd Keigwin for useful discussions and for generously providing access to Holocene samples. Rainer
Zahn kindly made comments on an earlier version of this manuscript. We are grateful to Helen Medley for technical support. We wish to express our gratitude to two anonymous reviewers. Their thoughtful comments helped to improve this manuscript greatly. This work was funded by the United Kingdom Natural Environment Research Council and supported by the NERC Radiocarbon Laboratory.

\section{References}

Aagaard, K., J. H. Swift, and E. C. Carmack (1985), Thermohaline circulation in the Arctic/ Mediterranean seas, J. Geophys. Res., 90, 48334846.

Adkins, J. F., E. A. Boyle, L. D. Keigwin, and E. Cortijo (1997), Variability of the North Atlantic thermohaline circulation during the last interglacial period, Nature, 390, 154-156.

Amos, A. F., A. L. Gordon, and E. D. Schneider (1971), Water masses and circulation patterns in the region of the Blake-Bahama Outer Ridge, Deep Sea Res. Oceanogr. Abstr., 18, $145-165$.

Bianchi, G. G., I. R. Hall, I. N. McCave, and L. Joseph (1999), Measurement of the sortable silt current speed proxy using the Sedigraph 5100 and Coulter Multisizer IIe: Precision and accuracy, Sedimentology, 46, 1001-1014.

Bianchi, G. G., M. Vautravers, and N. J. Shackleton (2001), Deep water variability under apparently stable North Atlantic Deep Water production during the last interglacial of the subtropical NW Atlantic, Paleoceanography, 16, 306-316.

Boyle, E. A. (1988), Vertical oceanic nutrient fractionation and glacial interglacial $\mathrm{CO}_{2}$ cycles, Nature, 331, 55-56.

Boyle, E. A., and L. D. Keigwin (1982), Deep circulation of the North-Atlantic over the last 200,000 years-Geochemical evidence, Science, 218, 784-787.

Boyle, E. A., and L. D. Keigwin (1987), North Atlantic thermohaline circulation during the past 20,000 years linked to high-latitude surface temperature, Nature, 330, 35-40.

Broecker, W. S., and E. Maier-Reimer (1992), The influence of air and sea exchange on the carbon isotope distribution in the sea, Global Biogeochem. Cycles, 6(3), 315-320.

Bryan, G. M. (1970), Hydrodynamic model of Blake Outer Ridge, J. Geophys. Res., 75, 4530-4537.

Chapman, M. R., and N. J. Shackleton (1998), Millennial-scale fluctuations in North Atlantic heat flux during the last 150,000 years, Earth Planet. Sci. Lett., 159, 57-70.

Chapman, M. R., and N. J. Shackleton (1999), Global ice-volume fluctuations, North Atlantic ice-rafting events, and deep-ocean circulation changes between 130 and $70 \mathrm{ka}$, Geology, 27, 795-798

Chapman, M. R., N. J. Shackleton, and J.-C. Duplessy (2000), Sea surface temperature variability during the last glacial-interglacial cycle: Assessing the magnitude and pattern of climate change in the North Atlantic, $\mathrm{Pa}$ laeogeogr., Palaeoclimatol., Palaeoecol., 157, $1-25$

Charles, C. D., J. D. Wright, and R. G. Fairbanks (1993), Thermodynamic influences on the marine carbon isotope record, Paleoceanography, 8, 691-697.

Clark, P. U., N. G. Pisias, T. F. Stocker, and A. J. Weaver (2002), The role of the thermohaline circulation in abrupt climate change, Nature, 415, 863-869.
Cottet-Puinel, M., A. J. Weaver, C. HillaireMarcel, A. de Vernal, P. U. Clark, and M. Eby (2004), Variation of Labrador Sea Water formation over the last glacial cycle in a climate model of intermediate complexity, Quat. Sci. Rev. $23,449-465$.

Curry, W. B., and D. W. Oppo (2005), Glacial water mass geometry and the distribution of $\delta^{13} \mathrm{C}$ of $\Sigma \mathrm{CO}_{2}$ in the western Atlantic Ocean, Paleoceanography, 20, PA1017, doi:10.1029/ 2004PA001021.

Curry, W. B., J.-C. Duplessy, L. D. Labeyrie, and N. J. Shackleton (1988), Changes in the distribution of $\delta^{13} \mathrm{C}$ of deep water $\Sigma \mathrm{CO}_{2}$ between the last glaciation and the Holocene, Paleoceanography, 3, 317-341.

Dickson, R. R., and J. Brown (1994), The production of North Atlantic Deep Water: Sources, rates, and pathways, J. Geophys. Res., 99, 12,319-12,341.

Duplessy, J.-C., N. J. Shackleton, R. G. Fairbanks, L. Labeyrie, D. Oppo, and N. Kallel (1988) Deepwater source variations during the last climatic cycle and their impact on the global deepwater circulation, Paleoceanography, 3, 343360.

Ewing, J., M. Ewing, and R. Leyden (1966), Seismic profile survey of the Blake Plateau, Am. Assoc. Pet. Geol. Bull., 50, 1948-1971.

Flood, R. D. (1979), Studies of deep-sea sedimentary microtopology in the North Atlantic Ocean, doctoral thesis, Joint Program in Oceanogr., Mass. Inst. of Technol./Woods Hole Oceanogr. Inst., Woods Hole, Mass.

Fronval, T., and E. Jansen (1996), Rapid changes in ocean circulation and heat flux in the Nordic Seas during the last interglacial period, Nature, 383, 806-810.

Fronval, T., E. Jansen, H. Haflidason, and H. P. Sejrup (1998), Variability in surface and deep water conditions in the Nordic Seas during the last interglacial period, Quat. Sci. Rev., 17 $963-985$.

Ganachaud, A., and C. Wunsch (2000), Improved estimates of global ocean circulation, heat transport and mixing from hydrographic data, Nature, 408, 453-456.

Hall, I. R., I. N. McCave, M. R. Chapman, and N. J. Shackleton (1998), Coherent deep flow variation in the Iceland and American Basin during the last interglacial, Earth Planet. Sci. Lett., 164, 15-21.

Haskell, B. J., and T. C. Johnson (1993), Surface sediment response to deepwater circulation on the Blake Outer Ridge, western North Atlantic: Paleoceanographic implications, Sediment. Geol., 82, 133-144.

Haskell, B. J., T. C. Johnson, and W. J. Showers (1991), Fluctuations in deep western North Atlantic circulation on the Blake Outer Ridge during the last deglaciation, Paleoceanography, 6, 21-31.

Heezen, B. C., C. D. Hollister, and W. F Ruddiman (1966), Shaping of the continenta rise by deep geostrophic currents, Science, 152, 502-508.
Heusser, L., and D. W. Oppo (2003), Millennialand orbital-scale climate variability in southeastern United States and in the subtropical Atlantic during marine isotope stage 5: Evidence from pollen and isotopes in ODP Site 1059, Earth Planet. Sci. Lett., 214, 483-490.

Hillaire-Marcel, C., A. de Vernal, G. Bilodeau, and A. J. Weaver (2001), Absence of deepwater formation in the Labrador Sea during the last interglacial period, Nature, 410 , 1073-1077.

Johns, E., R. A. Fine, and R. L. Molinari (1997), Deep flow along the western boundary of the Blake Bahama Outer Ridge, J. Phys. Oceanogr., 27, 2187-2208.

Johnson, T. C., E. L. Lynch, W. J. Showers, and N. C. Palczuk (1988), Pleistocene fluctuations in the Western Boundary Undercurrent on the Blake Outer Ridge, Paleoceanography, 3, 191-207.

Keigwin, L. D. (2004), Radiocarbon and stable isotope constraints on Last Glacial Maximum and Younger Dryas ventilation in the western North Atlantic, Paleoceanography, 19 , PA4012, doi:10.1029/2004PA001029.

Keigwin, L. D., and E. A. Boyle (1999), Surface and deep ocean variability in the northern Sargasso Sea during marine isotope stage $3, \mathrm{~Pa}$ leoceanography, 14, 164-170.

Keigwin, L. D., and G. A. Jones (1989), GlacialHolocene stratigraphy, chronology, and paleoceanographic observations on some North Atlantic sediment drifts, Deep Sea Res., Part A, 36, 845-867.

Keigwin, L. D., and M. A. Schlegel (2002), Ocean ventilation and sedimentation since the glacial maximum at $3 \mathrm{~km}$ in the western North Atlantic, Geochem. Geophys. Geosyst., 3(6), 1034, doi:10.1029/2001GC000283.

Keigwin, L. D., W. B. Curry, S. J. Lehman, and S. Johnsen (1994), The role of the deep ocean in North Atlantic climate change between 70 and 130 kyr ago, Nature, 371, 323-326.

Keigwin, L. D., et al. (1998), Proceedings of the Ocean Drilling Program Initial Report, vol. 172, Ocean Drill. Program, College Station, Tex.

Kroopnick, P. M. (1985), The distribution of $\mathrm{C}-13$ of sigma- $\mathrm{CO}_{2}$ in the world oceans, Deep Sea Res., Part A, 32, 57-84.

Laine, E. P., W. D. Gardner, M. J. Richardson, and M. A. Kominz (1994), Abyssal currents and advection of resuspended sediment along the northeastern Bermuda Rise, Mar. Geol., 119, 159-171.

Ledbetter, M. T., and W. L. Balsam (1985), Paleoceanography of the Deep Western Boundary Undercurrent on the North American continental margin for the past $25000 \mathrm{yr}$, Geology, 13, $181-184$.

Lehman, S. J., J. P. Sachs, A. M. Crotwell, L. D. Keigwin, and E. A. Boyle (2002), Relation of subtropical Atlantic temperature, high-latitude ice rafting, deep water formation, and European climate $130,000-60,000$ years ago, Quat. Sci. Rev., 21, 1917-1924. 
Lynch-Stieglitz, J., A. van Geen, and R. G. Fairbanks (1996), Interocean exchange of Glacial North Atlantic Intermediate Water: Evidence from subantarctic $\mathrm{Cd} / \mathrm{Ca}$ and carbon isotope measurements, Paleoceanography, 11, $191-201$

Lynch-Stieglitz, J., W. Curry, and N. A. Slowey (1999), A geostrophic transport estimate for the Florida Current from oxygen isotope composition of benthic foraminifera, Paleoceanography, 14, 360-373.

Mackensen, A., M. Rudolph, and G. Kuhn (2001), Late Pleistocene deep-water circulation in the subantarctic eastern Atlantic, Global Planet. Change, 30(3-4), 197-229.

Martinson, D. G., N. G. Pisias, J. D. Hays, J. Imbrie, T. C. Moore, and N. J. Shackleton (1987), Age dating and the orbital theory of the ice ages: Development of a high-resolution 0 to 300,000-year chronostratigraphy, Quat. Res., 27, 1-29.

Mauritzen, C. (1996), Production of dense overflow waters feeding the North Atlantic across the Greenland-Scotland Ridge. part 1: Evidence for a revised circulation scheme, Deep Sea Res., Part I, 43, 769-806.

McCave, I. N., and I. R. Hall (2006), Size sorting in marine muds: Processes, pitfalls and prospects for paleoflow-speed proxies, Geochem. Geophys. Geosyst., 7, Q10N05, doi:10.1029/ 2006GC001284

McCave, I. N., B. Manighetti, and S. G. Robinson (1995), Sortable silt and fine sediment size/composition slicing: Parameters for paleocurrent speed and paleoceanography, Paleoceanography, 10, 593-610.

McManus, J. F., G. C. Bond, W. S. Broecker, S. Johnsen, L. Labeyrie, and S. Higgins (1994), High-resolution climate records from the North Atlantic during the last interglacial, Nature, 371, 326-329.

North Greenland Ice Core Project Members (2004), High-resolution record of Northern Hemisphere climate extending into the last interglacial period, Nature, 431, 147-151.
Ohkouchi, N., T. I. Eglinton, L. D. Keigwin, and J. M. Hayes (2002), Spatial and temporal offsets between proxy records in a sediment drift, Science, 298, 1224-1227.

Oppo, D. W., and G. Fairbanks (1987), Variabil ity in the deep and intermediate water circulation of the Atlantic Ocean during the pas 25,000 years: Northern Hemisphere modulation of the Southern Ocean, Earth Planet. Sci. Lett., 86, 1-15.

Oppo, D. W., and M. Horowitz (2000), Glacial deep water geometry: South Atlantic benthic foraminiferal $\mathrm{Cd} / \mathrm{Ca}$ and $\delta^{13} \mathrm{C}$ evidence, Paleoceanography, 15, 147-160.

Oppo, D. W., and S. J. Lehman (1995), Suborbital timescale variability of North Atlantic Deep Water during the past 200,000 years, Paleoceanography, 10, 901-910.

Oppo, D. W., L. D. Keigwin, J. F. McManus, and J. L. Cullen (2001), Persistent suborbital climate variability in marine isotope stage 5 and Termination II, Paleoceanography, 16, 280292.

Ostermann, D. R., and W. B. Curry (2000), Calibration of stable isotopic data: An enriched delta $\mathrm{O}-18$ standard used for source gas mixing detection and correction, Paleoceanography, $15,353-360$.

Pickart, R. S. (1992), Water mass components of the North-Atlantic Deep Western Boundary Current, Deep Sea Res., Part A, 39, 15531572

Popp, B. N., F. G. Prahl, R. J. Wallsgrove, and J. Tanimoto (2006), Seasonal patterns of alkenone production in the subtropical oligotrophic North Pacific, Paleoceanography, 21 , PA1004, doi:10.1029/2005PA001165.

Rasmussen, T. L., D. W. Oppo, E. Thomsen, and S. J. Lehman (2003), Deep sea records from the southeast Labrador Sea: Ocean circulation changes and ice-rafting events during the last 160,000 years, Paleoceanography, 18(1), 1018, doi:10.1029/2001PA000736.

Reid, J. L. (1994), On the total geostrophic circulation of the North Atlantic Ocean: Flow patterns, tracers, and transports, Prog. Oceanogr., 33, 1-92.

Sachs, J. P., and S. J. Lehman (1999), Subtropical North Atlantic temperature 60,000 to 30,000 years ago, Science, 286, 756-759.

Sarnthein, M., K. Winn, S. J. A. Jung, J.-C. Duplessy, L. Labeyrie, H. Erlenkeuser, and G. Ganssen (1994), Changes in east Atlantic deep water circulation over the last 30,000 years: Eight time slice reconstructions, Paleoceanography, 9, 209-269.

Saunders, P. M. (1996), The flux of dense cold overflow water southeast of Iceland, J. Phys. Oceanogr, 26, 85-95.

Schmitz, W. J., Jr., and M. S. McCartney (1993), On the North Atlantic circulation, Rev. Geophys., 31, 29-49.

Shackleton, N. J. (1969), The last interglacial in the marine and terrestrial records, Proc. R. Soc London, Ser. B, 174, 135-154.

Stahr, F. R., and T. B. Sanford (1999), Transport and bottom boundary layer observations of the North Atlantic Deep Western Boundary Current at the Blake Outer Ridge, Deep Sea Res., Part II, 46, 205-243.

Talley, L., and M. McCartney (1982), Distribution and circulation of Labrador Sea Water, J. Phys. Oceanogr., 12, 1189-1205.

Yokokawa, M., and S. O. Franz (2002), Changes in grain size and magnetic fabric at Blake-Bahama Outer Ridge during the late Pleistocene (marine isotope stages 8-10), Mar. Geol., 189, 123-144.

G. G. Bianchi, H. K. Evans, and I. R. Hall, School of Earth, Ocean and Planetary Sciences, Cardiff University, Main Building, Park Place, Cardiff CF10 3YE, UK. (evansh2@cardiff. ac.uk)

D. W. Oppo, Department of Geology and Geophysics, Woods Hole Oceanographic Institution, Woods Hole, MA 02543, USA. 